
RESEARCH AND DEVELOPMENT

\author{
http://journal.unnes.ac.id/sju/index.php/higeia
}

\title{
Kebiasaan Sarapan pada Mahasiswa Aktif
}

\author{
Alman Putra ${ }^{1 凶}$, Dhea Nur Syafira ${ }^{1}$, Salma Maulyda ${ }^{1}$, Alfan Afandi $^{1}$, Sri Wahyuni $^{1}$ \\ ${ }^{1}$ Program Studi Kesehatan Masyarakat, Fakultas Ilmu Kesehatan, Universitas Ngudi Waluyo, Indonesia
}

\section{Info Artikel}

Sejarah Artikel:

Diterima 5 September

2018

Disetujui 19 Oktober

2018

Dipublikasikan 30

Oktober 2018

\section{Keywords:}

Breakfast, Nutrition Status,

Student

\section{DOI:}

https://doi.org/10.15294

/higeia.v2i4.26803

\begin{abstract}
Abstrak
Di Provinsi Jawa Tengah terdapat status gizi kurang sebanyak 7,5\%, status gizi normal sebanyak $53,1 \%$, status gizi gemuk sebanyak 28,1 , dan status gizi obes sebanyak $11,2 \%$. Asupan salah satu faktor yang mempengaruhi status gizi. Asupan salah satunya dapat dipenuhi dengan sarapan. Dalam penelitian ini menggunakan sampel Mahasiswa Semester 1-7 Program Studi Kesehatan Masyarakat Universitas Ngudi Waluyo yang berjumlah 77 orang. Jenis penelitian yang digunakan adalah penelitian yang bersifat deskriptif kualitatif dengan desain penelitian cross sectional. Dari hasil penelitian, dapat diketahui bahwa secara keseluruhan Mahasiswa Pogram Studi Kesehatan Masyarakat memiliki status gizi normal sebanyak 57 responden $(74 \%)$. Kebiasaan sarapan terdapat lebih banyak frekuensi sarapan responden 43 (56\%) jarang melakukan sarapan. Lebih banyak 64 responden $(83 \%)$ melakukan sarapan sebelum pukul 09.00. Sedangkan responden melakukan sarapan setiap pagi sebanyak 38 (49\%) hampir sama dengan responden melakukan sarapan hanya saat sebelum melakukan aktivitas sebanyak 39 (51 \%).
\end{abstract}

\section{Abstract}

In Central Java Province, there are less than 7.5\% nutrition status, 53.1\% normal nutrition status, 28.1 obese nutrition status, and obesity nutrition status of $11.2 \%$. Intake of one of the factors that affect nutritional status. One intake can be filled with breakfast. In this study used a sample of Students Semester 1-7 Ngudi Waluyo Community Health Studies Program which amounted to 77 people. The type of research used is descriptive qualitative research with cross sectional research design. From the results of the research, it can be seen that overall Student Pogram Studies Public Health has normal nutritional status as much as 57 respondents (74\%). Breakfast habits are more frequent breakfast 43 respondents (56\%) rarely do breakfast. More 64 respondents (83\%) did breakfast before 09.00. While respondents do breakfast every morning as much as 38 (49\%) almost the same as the respondent to do breakfast just before the activity as much as 39 (51\%).

\footnotetext{
Alamat korespondensi:

Jalan Diponegoro no. 186, Gedanganak

Ungaran Timur, Kab. Semarang 50519

E-mail: almanputra@gmail.com
}

p ISSN 1475-362846

e ISSN 1475-222656 


\section{PENDAHULUAN}

Dalam pemenuhan gizi masyarakat, indonesia saat ini sedang menghadapi masalah besar. Untuk menyelesaikan masalah ini diperlukan anggaran yang cukup besar dan kerjasama lintas sektor. Beban gizi ganda merupakan tantangan bagi sumber daya manusia di Indonesia. Tantangan tersebut dapat muncul di berbagai tahapan siklus kehidupan dan sangat berpengaruh kepada daya saing manusia Indonesia. Dampak permasalahan gizi muncul pada usia dini tidak terbatas hanya pada status gizi anak saja. Sebagai contoh anak berbadan pendek, anak yang kegemukan atau anak dengan status gizi buruk (Hardinsyah, 2016).

Status gizi adalah keadaan tubuh akibat mengkonsusmsi makanan, penyerapan dan penggunaan zat-zat gizi. Status gizi dibedakan menjadi tiga yaitu status gizi kurang, status gizi normal, dan status gizi lebih. Penentuan status gizi dapat dilakukan dengan beberapa cara salah satu yang sering digunakan adalah Indeks Masa Tubuh (IMT) (Sasmito, 2015a).

Perlunya pemenuhan zat gizi pada usia remaja, terutama remaja putri berhubungan dengan perannya dimasa yang akan datang sebagai calon ibu. Kondisi seseorang pada masa dewasa ditentukan oleh keadaan pada masa remaja. Remaja putra dan putri memiliki porsi asupan yang sedikit berbeda. Hal ini disebabkan adanya perubahan biologis dan fisiologis, sehingga pemenuhan kebutuhan nutrisi antara ke duanya berbeda. Pada usia remaja keadaan gizi dan kesehatan harus sangat diperhatikan agar berdampak baik di masa mendatang mengingat wanita memiliki peran melahirkan generasi berikutnya (Wardoyo, 2013). Pada masa inilah, remaja putri mengalami menstruasi awal dalam fase hidupnya. Dalam hal ini, menstruasi menuntut kebutuhan zar besi lebih banyak.

Gizi yang tidak seimbang baik kekurangan maupun kelebihan gizi akan menurunkan kualitas sumber daya manusia. Kurangnya asupan gizi yang mengakibatkan kurang gizi yaitu terlalu kurus dan dapat terkena anemia karena kekurangan zat besi. Kurangnya asupan protein secara konsisten pada remaja dapat berakibat pertumbuhan linear berkurang, keterlambatan maturasi seksual, serta berkurangnya akumulasi massa tubuh tanpa lemak. Selain itu masalah gizi yang sering muncul adalah kelebihan asupan gizi yang dapat menyebabkan obesitas. Penelitian menunjukkan bahwa dampak overweight dan obesitas terhadap kualitas hidup terkait kesehatan. Obesitas meningkatkan risiko kesakitan dan kematian serta menyebabkan keterhambatan fungsi fisik dan psikologis yang berdampak pada kualitas hidup (Niswah, 2014).

Pada data Penilaian Status Gizi 2016 bahwa penduduk dewasa umur $>18$ tahun berdasarkan IMT nasional terdapat status gizi kurus sebanyak 6,7 \%, status gizi normal sebanyak $54,8 \%$, status gizi gemuk sebanyak $27,9 \%$, dan status gizi obesitas sebanyak 10,6 \%. Sedangkan data. di Provinsi Jawa Tengah terdapat status gizi kurang sebanyak 7,5\%, status gizi normal sebanyak $53,1 \%$, status gizi gemuk sebanyak 28,1 , dan status gizi obes sebanyak 11,2 \% (Isa, 2011).

Asupan merupakan salah satu faktor yang mempengaruhi status gizi. Asupan salah satunya dapat dipenuhi dengan sarapan. Pada dasarnya sarapan akan memberikan kontribusi penting akan beberapa zat gizi yang diperlukan tubuh seperti protein, lemak, vitamin, dan mineral. Bila tidak terbiasa sarapan secara terus menerus akan mengakibatkan berat badan dan daya tahan tubuh, kurang gizi, dan anemia zat besi (Silalahi, 2011). Obesitas orang yang tidak sarapan merasa lebih lapar pada siang dan malam hari daripada orang yang sarapan pagi karena asupan energi cenderung meningkat ketika sarapan dilewatkan. Mereka akan mengkonsumsi lebih banyak makanan pada waktu siang dan malam hari. Takut menjadi gemuk juga sering dijadikan alasan untuk meninggalkan sarapan. Kebiasaan tidak sarapan pagi yang terus menerus akan mengakibatkan pemasukan gizi menjadi berkurang dan tidak seimbang.

Kebiasaan sarapan terkadang sering diabaikan oleh setiap orang, padahal sarapan 
sangat penting untuk memenuhi salah satu asupan gizi harian yang berguna untuk mendukung aktivitas setiap hari. Apabila seseorang selalu membiasakan diri untuk sarapan maka akan meningkatkan kualitas gizinya sehingga dapat berkontribusi pada asupan dan kebutuhan zat gizi harian. Berdasarkan hasil penelitian bahwa survei di lima kota besar menunjukan, $17 \%$ orang dewasa tidak sarapan, dan $13 \%$ tidak sarapan setiap hari. Angka tidak sarapan pada anak-anak bervariasi dari 17\% di Jakarta, hingga 59\% di Yogyakarta (Setiyawan, 2017).

Kehidupan sosial mahasiswa sangat mempengaruhi perilaku hidup sehatnya khususnya kebiasaan sarapan setiap hari, akan tetapi masih terdapat mahasiswa yang tidak rutin melakukan sarapan. Hal yang menjadi masalah pada mahasiswa yang tidak rutin melakukan sarapan di karenakan meraka tinggal di luar kota dan kost di sekitar kampus, sehingga mereka harus menyiapkan makanan sendiri ataupun mereka harus mencari warung makan untuk sarapan, sedangakan jadwal kuliah pagi membuat mereka tergesa-gesa dan akhirnya mereka harus menunda sarapan. Lain halnya dengan mahasiswa yang tinggal di rumahnya sendiri, ke banyakan dari mereka lebih sering melakukan sarapan pagi karena sudah disediakan makanan untuk sarapan oleh orang tua.

Penelitian ini dilakukan di Universitas Ngudi Waluyo Program Studi Kesehatan Masyarakat dengan tujuan penelitian umum yaitu mengetahui kebiasaan sarapan terhadap status gizi mahasiswa dan tujuan khusus dari penelitian ini menggambarkan status gizi dan kebiasaan sarapan mahasiswa.

Manfaat dari penelitian ini Memberikan informasi mengenai status gizi dan pentingnya sarapan bagi Mahasiswa Program Studi Kesehatan Maasyarakat Universitas Ngudi Waluyo.

\section{METODE PENELITIAN}

Jenis penelitian yang digunakan adalah penelitian yang bersifat deskriptif kualitatif yaitu menggambarkan status gizi dan kebiasaan sarapan pagi mahasiswa, dengan desain penelitian cross sectional yaitu melakukan pendekatan terhadap responden dengan cara observasi dan pengumpulan data pada waktu yang sama. Teknik pengumpulan data menggunakan kuesioner perilaku tentang kebiasaan sarapan mahasiswa dan pengisian data pribadi yaitu nama, semester, jenis kelamin, umur, tinggi badan, dan berat badan

Lokasi penelitian dilaksanakan di kampus Universitas Ngudi Waluyo Ungaran Gedung G Program Studi Kesehatan Masyarakat J1. Gedongsongo, Candirejo, Ungaran, Kabupaten Semarang, Jawa Tengan. Dalam penelitian ini jumlah populasi adalah Mahasiswa Semester 1-

7 Program Studi Kesehatan Masyarakat Universitas Ngudi Waluyo yang berjumlah 91 orang. Jumlah sampel yang digunakan adalah sebesar 77 responden. Varibel pada penelitian ini terdiri dari variabel bebas yaitu kebiasaan sarapan pagi mahasiswa, variabel terikat yaitu status gizi mahasiswa.

Instrumen penelitian yang digunakan dalam penelitian ini adalah menggunakan kuesioner untuk mengetahui status gizi serta mengetahui kebiasaan sarapan mahasiswa yang berupa frekuensi sarapan, waktu sarapan, cara memperoleh sarapan, dan jenis sarapan.

Dalam penelitian ini menggunakan teknik pengambilan sampel acak berdasar area karena saat sedang melakukan penelitian dari seluruh mahasiswa yang berjumlah 91 orang hanya terdapat 77 responden yang masuk saat mengikuti perkuliahan. Maka dari itu kami hanya mengambil jumlah sampel yang hanya ada pada saat mengikuti perkuliahan.

Tahap pengolahan data meliputi pemberian kode diberikan oleh penelitian pada kuesiner yang telah diisi oleh responden, pengeditan data, entri data, skoring data, dan cleaning data. Data yang telah terkumpul dilakukan pemerikasan data satu demi satu yang meliputi jumlah lembaran yang telah dibagikan apakah sama dengan jumlah sempel yang ditentukan dan mengkoreksi setiap lembaran apakah sudah terisi semua serta pemberian kode pada setiap lembar quesioner. Pengolahan data 
menggunakan program komputer Microsoft Excel, data disajikan dalam bentuk tabel dengan analisis data yang berupa narasi. Data yang diolah dan dianalisis secara deskriptif yaitu usia, jenis kelamin, status gizi, dan kebiasaan sarapan.

Prosedur penelitian dalam penelitian ini adalah kegiatan menyusun rancangan awal penelitian antara lain mencari informasi awal melalui review dokumen-dokumen yang relevan seperti jurnal, berita, buku-buku, dan juga datadata dari instansi terkait yang dapat dipertanggungjawabkan. Setelah menyusun rancangan awal penelitian, selanjutnya memilih tempat penelitian yang dilanjutkan mengurus perizinan. Dalam memilih lapangan penelitian, peneliti tidak secara langsung terjun ke lapangan untuk observasi dan perizinan pada penelitian ini ditujukan kepada Kepala Kesbangpolinmas Kota Semarang dan Dinas Kesehatan Kota Semarang. Selain itu ada pula perizinan informal, yaitu perizinan kepada beberapa pejabat daerah di lokasi pengambilan data.

Teknik yang digunakan untuk memeriksa keabsahan data dalam penelitian ini dilakukan dengan menggunakan teknik triangulasi. Triangulasi adalah teknik pemeriksaan keabsahan data yang memanfaatkan sesuatu yang lain di luar data itu untuk keperluan pengecekan data atau sebagai pembanding terhadap data tersebut. Triangulasi yang digunakan dalam penelitian ini adalah triangulasi sumber. Triangulasi sumber dilakukan dengan cara mengecek data yang telah diperoleh melalui beberapa sumber. Informan berperan sebagai triangulasi adalah kasi kesos kelurahan Meteseh dan Kelurahan Tembalang, kasi kesos Kecamatan Tembalang, Pemegang Program P2P Puskesmas Rowosari, Koordinator Gasurkes DBD Dinas Kesehatan Kota Semarang, dan perwakilan masyarakat (PPJ) dari masing-masing kelurahan.

Kegiatan analisis data yang dilakukan dalam penelitian ini antara lain, 1) Reduksi data, Reduksi data dilakukan untuk menghilangkan/membuang data-data yang tidak diperlukan. Mereduksi data berati merangkum, memilih hal-hal yang pokok, dan memfokuskan pada hal-hal yang penting., 2) Penyajian data, Dalam penelitian kualitatif penyajian data bisa dilakukan dalam bentuk uraian singkat (narasi), bagan, tabel, grafik, dan sejenisnya dengan penyajian data, maka akan lebih mudah memahami apa yang terjadi karena data sudah terorganisir dan tersusun., 3) Penarikan kesimpulan, Data yang telah direduksi dan disajikan kemudian dilakukan penarikan kesimpulan berdasarkan pengamatan secara menyeluruh dari data-data yang sudah terkumpul pada tahap penelitian. Penarikan kesimpulan dalam bentuk penjelasan kalimatkalimat yang mudah dipahami.

\section{HASIL DAN PEMBAHASAN}

Penelitian ini dilakukan di Universitas Ngudi Waluyo Fakultas Ilmu Kesehatan Program Studi Kesehatan Mayarakat dengan responden Semester 1 sampai dengan Semester 7 yang berjumlah 77 orang. Berdasarkan hasil penelitian diperoleh data karakteristik responden disajikan pada Tabel 1.

Secara keseluruhan responden 32 (42\%) lebih banyak pada semester 1 dan responsen 8 (10\%) lebih sedikit pada semester 5 , sedangkan pada kelompok umur 19 tahun lebih banyak 26

Tabel 1. Karakteristik Responden

\begin{tabular}{lcc}
\hline Variabel & Frekuensi & Persentase (\%) \\
\hline Semester & & \\
1 & 32 & 42 \\
3 & 24 & 31 \\
5 & 8 & 10 \\
7 & 13 & 17 \\
Total & 77 & 100 \\
Umur (tahun) & & \\
17 & 3 & 4 \\
18 & 24 & 31 \\
19 & 26 & 34 \\
20 & 8 & 10 \\
21 & 13 & 17 \\
22 & 1 & 1 \\
23 & 2 & 3 \\
Total & 77 & 100 \\
Jenis kelamin & & \\
Perempuan & 68 & 88 \\
Laki-laki & 9 & 12 \\
Total & 77 & 100 \\
\hline
\end{tabular}


Tabel 2. Status Gizi dan Kebiasaan Sarapan Mahasiswa Program Studi Kesehatan Masyarakat Universitas Ngudi Waluyo

\begin{tabular}{lcc}
\hline \multicolumn{1}{c}{ Variabel } & $\begin{array}{c}\text { Freku } \\
\text {-ensi }\end{array}$ & $\begin{array}{c}\text { Persenta } \\
\text {-se (\%) }\end{array}$ \\
\hline Status gizi & & \\
Normal & 57 & 74 \\
Kurus & 15 & 19 \\
Berat badan lebih & 2 & 3 \\
Obesitas & 3 & 4 \\
$\quad$ Total & 77 & 100 \\
Frekuensi sarapan & & \\
Jarang sarapan & 43 & 56 \\
Sering sarapan & 34 & 44 \\
Total & 77 & 100 \\
Waktu sarapan & & \\
Pukul <09.00 WIB & 64 & 83 \\
Pukul $\geq 09.00$ WIB & 13 & 17 \\
Total & 77 & 100 \\
Setiap pagi & 38 & 49 \\
Sebelum & & \\
beraktifitas & 39 & 51 \\
Total & 77 & 100 \\
Cara memperoleh & & \\
sarapan & & \\
Disiapkan di rumah & 28 & 36 \\
Dibeli di warung & 49 & 64 \\
Total & 77 & 100 \\
Jenis sarapan & & \\
Makanan pokok & 64 & 83 \\
Makanan alternatif & 13 & 17 \\
Total & 77 & 100 \\
\hline
\end{tabular}

(34\%) responden dan responden 1 (1\%) lebih sedikit pada kelompok umur 22 tahun. Pada usia mahasiswa berada pada masa remaja akhir (18-21 tahun) (Rosyidah, 2016). Faktor umur sangat penting dalam penentuan status gizi seseorang. Kesalahan dalam penentuan umur akan mengakibatkan interpretasi status gizi menjadi salah. Hasil pengukuran tinggi badan dan berat badan akan menjadi tidak akurat apabila tidak disertai dengan penentuan umur yang tepat (Sasmito, 2015a). Jenis kelamin pada penelitian ini lebih dominan perempuan sebanyak 68 (88 \%) dan laki-laki sebanyak 9 $(12 \%)$. Didukung oleh penelitian lain yang menyatakan bahwa proporsi laki-laki sebanyak
(48.8\%), sedangkan perempuan sebanyak (51.2\%) (Sasmito, 2015a).

Berdasarkan tabel 2 dari hasil penelitian, dapat diketahui bahwa secara keseluruhan Mahasiswa Pogram Studi Kesehatan Masyarakat Universitas Ngudi Waluyo memiliki status gizi normal sebanyak 57 responden (74 \%). Namun masih terdapat responden dengan masalah status gizi kurus sejumlah 15 responden (19\%), proporsi status gizi berat badan lebih 2 responden (3\%) hampir sama dengan status gizi obesitas yaitu sebesar 4 $\% \quad$ (3 responden). Hasil penelitian lain menyatakan bahwa 1804 remaja di Cina mengalami status gizi gemuk dan obesitas lebih banyak dialami oleh laki-laki dari pada remaja perempuan, yaitu sebesar $19.4 \%$ untuk remaja laki-laki dan $13.2 \%$ untuk remaja perempuan (Sasmito, 2015b) . Kebutuhan gizi pada pria lebih besar dibandingkan dengan perempuan sehingga setiap kali makan porsinya lebih banyak (Sasmito, 2015a) .

Status gizi pada mahasiswa diukur dengan menggunakan antropometri dengan mengetahui umur, jenis kelamin, berat badan, dan tinggi badan responden. Status gizi dapat diketahui dengan menghitung Indeks Massa Tubuh (IMT). Indeks Massa Tubuh dihitung dengan cara membagi bobot badan $(\mathrm{kg})$ dengan kudrat tinggi badan $(\mathrm{m}): \mathrm{IMT}=\mathrm{BB} / \mathrm{TB}^{2}, \mathrm{BB}$ adalah bobot badan $(\mathrm{kg})$ dan $\mathrm{TB}$ adalah tinggi badan (m). Badan Kesehatan Dunia (WHO) tahun 2000 telah mengeluarkan kategori IMT yang cocok untuk masyarakat Asia. Untuk praktisnya, kriteria IMT adalah kurus (IMT $<18$ ), normal (IMT = 18-25), gemuk sehat (IMT = 25-30), dan gemuk tidak sehat atau obesitas (IMT >30). Dapat diketahui bahwa dari hasil penelitian masih terdapat mahasiswa yang mengalami masalah status gizi. Ketidakseimbangan antara asupan kebutuhan ataupun kecukupan dapat mengakibatkan masalah status gizi, baik masalah status gizi kurang maupun gizi lebih (Anzarkusuma, 2014).

Status gizi merupakan keadaan tubuh seseorang yang diakibatkan oleh konsumsi, penyerapan, dan penggunaan zat gizi makanan. 
Konsumsi makanan yang tidak sesuai dengan kebutuhan dapat menyebabkan gizi salah (malnutrisi) yang dapat berupa gizi lebih dan kurang .Dengan mengetahui status gizi seseorang tersebut status gizinya baik atau tidak baik (Anzarkusuma, 2014; Cintari, 2011). Dari seluruh responden yang memiliki status gizi kurang dapat terjadi karena apabila jenis dan jumlah makanan yang dikonsumsi saat sarapan belum memenuhi kecukupan gizinya. Kebiasaan sarapan memiliki peran penting terhadap kondisi tubuh seseorang. Dalam jangka panjang, kebiasaan sarapan akan berpengaruh terhadap status gizi. Sarapan merupakan kegiatan yang penting sebelum melakukan aktivitas yang lain pada setiap hari (Soedibyo, 2016).

Berdasarkan hasil penelitian bahwa dari seluruh 77 responden terdapat lebih banyak frekuensi sarapan responden 43 (56 \%) jarang melakukan sarapan. Beberapa mahasiswa yang tinggal di kost mereka lebih jarang melakukan sarapan sebelum kuliah pagi dengan alasan malas, dan tidak sempat membeli makanan. Berbeda dengan mahasiswa yang laju lebih sering melakukan sarapan pagi karena telah disiapkan makanan oleh orang tua. Penelitian lain mengungkapkan alasan terbanyak subjek penelitiannya tidak sarapan adalah tidak sempat atau tidak memiliki waktu karena terburu-buru sekolah, serta diet penurunan berat badan (Ilyatun Niswah, 2014). Penelitian di negara maju juga menyatakan prevalensi anak dan remaja yang melewatkan sarapan berkisar antara 12-34\% (Niswah, 2014)

Sarapan merupakan kegiatan yang dilakukan mulai dari bangun tidur di pagi hari sampai dengan pukul 09.00 untuk memenuhi sekitar 15-25\% kebutuhan gizi dalam sehari agar terwujudnya hidup sehat, aktif dan cerdas. Frekuensi sarapan dari penilitian ini adalah kebiasaan sarapan responden setiap hari. Frekuensi sarapan berkontribusi untuk meregulasi selera makan dan pencegahan (Mariza, 2013 ).

Sarapan termasuk kedalam salah satu 10 pesan dari gizi seimbang. Sarapan juga dapat menyumbang seperempat dari kebutuhan gizi sehari yaitu sekitar 400-500 kalori dengan 8-9 gram protein (Saufika, 2012). Seseorang yang tidak melakukan sarapan merasa lebih lapar pada siang dan malam hari daripada seseorang yang melakukan sarapan karena asupan energi cenderung meningkat ketika sarapan dilewatkan. Merekan akan lebih banyak mengkonsumsi makanan lebih banyak pada waktu siang dan malam hari. Asupan makanan lebih banyak pada malam hari akan mengakibatkan meningkatnya glukosa yang disimpan sebagai glikogen. Aktivitas fisik sangat rendah sehingga glikogen akan disimpan dalam bentuk lemak. Hal tersebut yang dapat mengakibatkan seseorang menjadi obesitas (Achadi, 2010)

Berdasarkan tabel 2 disajikan bahwa dari keseluruhan reponden lebih banyak 64 responden (83\%) melakukan sarapan sebelum pukul 09.00. Sedangkan responden melakukan sarapan setiap pagi sebanyak 38 (49\%) hampir sama dengan responden melakukan sarapan hanya saat sebelum melakukan aktivitas sebanyak 39 (51\%).

Visi Indonesia Sehat 2015 bertujuan untuk mensejahterakan rakyat dalam peningkatan kesehatan termasuk gizi. Undangundang nomor 36 Tahun 2009 tentang Kesehatan pasal 141 ayat 1 menyatakan bahwa upaya perbaikan gizi masyarakat ditujukan untuk peningkatan mutu gizi perseorangan dan masyarakat (Direktorat Jenderal Bina Gizi dan KIA, 2011).

Salah satu upaya peningkatan kesehatan adalah perbaikan gizi terutama pada usia sekolah khususnya 6-12 tahun. Makan pagi atau sarapan adalah kegiatan mengkonsumsi makanan yang mengandung gizi seimbang dan memenuhi $20 \%$ - $25 \%$ dari kebutuhan energi total dalam sehari yang dilakukan pada pagi hari sebelum kegiatan belajar di sekolah (Ali, 2003). Sarapan pagi pada anak sekolah bertujuan untuk mencukupi kebutuhan energi selama beraktivitas di sekolah serta dapat meningkatkan konsentrasi dan daya ingat anak. Kebiasaan sarapan juga termasuk dalam salah satu 13 pesan dasar gizi seimbang (Alamin, 2014). 
Sarapan sebaiknya mengandung makanan sumber karbohidrat, protein, tinggi serat, dan rendah lemak (Noviani, 2011). Melewatkan sarapan dapat berisiko untuk menjadi obesitas dan memiliki gangguan kesehatan (Muchtar, 2011). Obesitas dapat terjadi karena ketika anak tersebut melewatkan sarapan dan merasa lapar maka mereka akan mengkonsumsi makanan berkalori lebih tinggi yang didapatkan dari makanan jajanan. 5,6 Penelitian di Amerika Serikat menunjukkan bahwa anak-anak dan remaja yang terbiasa melewatkan sarapan akan memiliki risiko (Miko, 2016) kali lebih tinggi untuk ngemil dan sulit mengontrol nafsu makan mereka sehingga dapat menyebabkan obesitas (Mariza, 2013)

Penelitian yang dilakukan Triyanti di SD Citarum 01,02,03, dan 04 Semarang menunjukkan masih terdapat $34,83 \%$ anak SD jarang sarapan dan terdapat hubungan antara kebiasaan makan pagi dengan prestasi belajar (Lentini, 2014; Maharibe, 2014). Survey yang dilakukan Pergizi Pangan Indonesia tahun 2010 pada 35 ribu anak usia sekolah dasar menunjukkan $44,6 \%$ anak yang sarapan memperoleh asupan energi kurang dari 15\% kebutuhannya.

Kelaparan saat di sekolah akan menyebabkan anak jajan di sekolah, apalagi hanya sekitar 5\% dari anak-anak tersebut membawa bekal dari rumah, sehingga kemungkinan untuk membeli makanan jajanan lebih tinggi (Al-Oboudi, 2010) BPOM RI tahun 2009 dalam Pangan Jajanan Anak Sekolah menunjukkan bahwa makanan jajanan memberikan kontribusi masing-masing sebesar $31,1 \%$, dan $27,4 \%$ terhadap keseluruhan asupan energi dan protein anak sekolah dasar (Mariza, 2013) Sebuah studi di Amerika Serikat menunjukkan bahwa anak mengkonsumsi lebih dari sepertiga kebutuhan kalori sehari yang berasal dari makanan jajanan jenis fast food dan soft drink dapat menyebabkan obesitas (Adair LS, 2005)

Hasil RISKESDAS tahun 2010 menunjukkan prevalensi overweight dan obesitas pada anak sekolah (6-12 tahun) sebesar 9,2\%. Sejak tahun 1970 hingga 2010, kejadian obesitas meningkat dua kali lipat pada anak usia 2-5 tahun dan usia 12-19 tahun, bahkan meningkat tiga kali lipat pada anak usia 6-11 tahun. Di Indonesia, penelitian pada anak sekolah dasar di beberapa kota besar menunjukkan kisaran jumlah 2,1-25\% (Alamin, 2014).

Prevalensi obesitas pada anak sekolah usia 6-12 tahun di propinsi Jawa Tengah pada tahun 2010 lebih tinggi dari prevalensi nasional yaitu $10,9 \%$. Prevalensi obesitas dan overweight di Semarang tahun 2004 pada murid sekolah dasar usia 6-7 tahun adalah sebesar 10,6\% dan 9,1\% (Kusprasetia, 2016). Obesitas pada dewasa dapat bermula semenjak anak-anak, dan obesitas dapat menjadi faktor risiko dari berbagai penyakit degeneratif seperti hipertensi, diabetes mellitus, dan jantung (Mariza, 2013)

Sarapan adalah kegiatan penting sebelum melakukan aktivitas fisik pada hari tersebut, mengingat bahwa tubuh tidak mendapatkan makanan selama sekitar 10 jam sejak malam hari, serta melakukan sarapan dapat menyumbang $25 \%$ dari kebutuhan total energi sehari-hari (Sartika, 2012; Nurwijayanti, 2018). Sarapan yang baik yaitu sarapan yang selalu dilakukan pada pagi hari bukan menjelang makan siang dan tidak perlu dibedakan antara sebelum melakukan aktivitas seperti kerja dan sekolah serta hari libur. Sarapan dimulai dari bangun tidur di pagi hari hingga pukul 09.00 (Kusprasetia, 2016).

Sarapan sering dilupakan oleh sebagian individu yang sibuk tetapi sarapan sangat penting untuk menunjang kesibukan individu pada saat itu. Zat gizi yang dikonsumsi pada saat sarapan berpengaruh baik terhadap kegiatan yang berlanjut sampai siang bahkan malam hari. Rata-rata kebiasaan sarapan sering dilewatkan oleh sebagian orang sehingga dapat berakibat tubuh menjadi kurang sehat. Seseorang yang tidak sarapan akan mengalami kekurangan energi dan motivasi untuk beraktivitas selain itu kekurangan gizi dan kekurangan zat gizi mikro dapat memberikan dampak terhadap keadaan fisik, mental, kesehatan, dan menurunkan fungsi kognitif (Setiyawan, 2017). 
Dari hasil penelitian sebanyak 77 responden cara memperoleh sarapan setiap hari responden lebih banyak di beli di warung sebanyak 49 responden (64\%) dengan keterangan bahwa mahasiswa lebih banyak berasal dari luar kota sehingga mereka bertempat tinggal di kost ataupun di asrama. Dalam memperoleh makanan mahasiswa yang tinggal di kost memiliki beberapa cara yaitu membeli di warung dan memasak sendiri. Bagi mereka yang memasak sendiri keteraturan pola makannya sangat tergantung kedisiplinan mereka mengatur waktu dan uang saku. Tidak jarang dijumpai mahasiswa yang sarapan dan makan siang disatukan karena terlambat bangun atau kondisi keungan kurang membaik. Anak kost biasanya mengalami ada waktu tertentu uang mereka banyak dan ada waktu uang mereka sedikit bahkan sama sekali tidak ada (Kalsum, 2016).

Berdasarkan hasil penelitian dapat diketahui bahwa 64 responden (83 \%) lebih dominan dengan makanan pokok saat sarapan setiap hari, namun tidak menutup kemungkinan masih terdapat 13 responden (17\%) melakukan sarapan dengan menggunakan makanan alternatif. Sarapan yang sesuai dengan menu seimbang (kandungan gizi yang seimbang terdiri dari karbohidrat, protein, lemak, vitamin, dan mineral) yang terdiri nasi, sayur/buah, lauk pauk dan susu, dapat memenuhi kebutuhan akan vitamin dan mineral (Sartika, 2012).

Jenis makanan yang dikonsumsi saat sarapan sangat menentukan kualitas sarapan dan energi yang dihasilkan dari sarapan itu sendiri. Sarapan dapat menyediakan karbohidrat yang digunakan untuk meningkatkan kadar glukosa darah, produktivitas kerja meningkat. Konsumsi saat sarapan lebih baik terdiri dari makanan dan minuman yang beraneka ragam mengandung unsur gizi yang di butuhkan oleh tubuh dan mengacu pada pedoman gizi seimbang yaitu pemenuhan karbohidrat dan zat gizi lainnya seperti protein, lemak, vitamin, mineral, air, dan serat. Namun, secara umum jenis komposisi pangan telah memenuhi kebutuhan minimal sarapan yakni makanan pokok seperti nasi, sayur, dan lauk pauk hewani. Jenis makanan alternatif seperti roti, umbi-umbian, sereal juga dapat dijadikan sebagai makanan alternatif sarapan. Akan tetapi, kandungan zat gizi lebih banyak hanya mengandung karbohidrat (Kusprasetia, 2016; Perdana, 2013 ).

Makanan yang dikonsumsi setiap hari harus terpenuhi secara kualitas maupun kuantitas. Makanan yang seimbang dari segi kualitas maupun kuantitasnya akan mendukung kemampuan seseorang dalam melakukan aktivitas sehari-hari. Sarapan yang baik terdiri dari makanan sumber zat tenaga, sumber zat pembangun, dan sumber zat pengatur. Dalam menuyusun menu sarapan perlu memperhatikan kelengkapan kandungan gizi yaitu karbohidrat, protein, vitamin, mineral, sayur dan buah tinggi serat, dan rendah lemak (Achadi, 2010).

\section{PENUTUP}

Berdasarkan hasil penelitian kebiasaan sarapan terhadap status gizi pada Mahasiswa Universitas Ngudi Waluyo Program Studi Kesehatan Masyarakat secara umum memiliki status gizi normal, dan hanya sedikit yang memiliki status gizi kurus, gemuk dan obesitas. Sebaliknya pada penelitian ini kebiasaan sarapan pada mahasiswa berbanding terbalik dengan status gizi, yang mana bahwa kebiasaan sarapan masih jarang dilakukan oleh mahasiswa. Kondisi ini tidak menunjukkan bahwa kebiasaan sarapan dapat berpengaruh terhadap status gizi pada Mahasiswa Universitas Ngudi Waluyo Program Studi Kesehatan Masyarakat.

Penelitian ini hanya bersifat deskriptif, sehingga belum memberikan penjelasan tentang faktor yang berhubungan atau berpengaruh terhadap variabel kebiasaan sarapan baik secara kualitatif dan kuantitatif. Oleh sebab itu saran yang diberikan untuk penulisan selanjutnya yaitu dapat meneliti lebih komprehensif tentang faktor yang mempengaruhi kebiasaan dan bagaimana strategi atau perlakuan yang dapat mengatasi kebiasaan sarapan mahasiswa maupun orang pada umumnya yang masih buruk. 


\section{DAFTAR PUSTAKA}

Achadi, E., Pujonarti, S. A., Sudiarti, T., Rahmawati, R., Kusharisupeni, K., Mardatillah, M., \& Putra, W. K. 2010. Sekolah dasar pintu masuk perbaikan pengetahuan, sikap, dan perilaku gizi seimbang masyarakat. Kesmas: National Public Health Journal, 5(1): 42-48.

Alamin, R. L., and Syamsianah, A. 2014. Hubungan Sarapan Pagi di Rumah dan Jumlah Uang Saku dengan Konsumsi Makanan Jajanan di Sekolah pada Siswa SD N Sukorejo 02 Semarang. Jurnal Gizi, 3(1).

Al-Oboudi, L. M. 2010. Impact of breakfast eating pattern on nutritional status, glucose level, iron status in blood and test grades among upper primary school girls in Riyadh City, Saudi Arabia. Pakistan Journal of Nutrition, 9(2): 106-111.

Anzarkusuma, I. S., Mulyani, E. Y., Jus'at, I., \& Angkasa, D. 2014. Status Gizi Berdasarkan Pola Makan Anak Sekolah Dasar Di Kecamatan Rajeg Tangerang (Nutritional Status Based On Primary School Student's Dietary Intake In Rajeg District Tangerang City). Indonesian Journal of Human Nutrition, 1(2): 135-148.

Cintari, L., Padmiari, I. A. E., \& Utami, I. G. A. S. 2011. Perbedaan Kejadian Obesitas Pada Anak Sekolah Berdasarkan Jenis Sarapan Dan Faktor Keturunan. J Skala Husada, 8(2): 112-8.

Hardinsyah, H., \& Aries, M. 2016. Jenis pangan sarapan dan perannya dalam asupan gizi harian anak usia 6-12 tahun di indonesia. Jurnal Gizi dan Pangan, 7(2): 89-96.

Isa, K. A. M., \& Masuri, M. G. 2011. The association of breakfast consumption habit, snacking behavior and body mass index among university students. American Journal of Food and Nutrition, 1(2): 55-60.

Kalsum, U., \& Halim, R. (2016). Kebiasaan Sarapan Pagi berhubungan dengan Kejadian Anemia pada Remaja di SMA Negeri 8 Muaro Jambi. Jurnal Penelitian Universitas Jambi: Seri Sains, 18(1).

Kusprasetia, M. T. 2016 Hubungan antara Kebiasaan Sarapan dengan Status Gizi dan Prestasi Belajar pada Anak Sekolah Dasar di Kota Bogor Ilmu Gizi pada Departemen Gizi Masyarakat 47.

Lentini, B., \& Margawati, A. 2014. Hubungan kebiasaan sarapan dan status hidrasi dengan konsentrasi berfikir pada remaja. Journal of Nutrition College, 3(4): 631-637.

Maharibe, C. C. 2014. Hubungan Pengetahuan Gizi Seimbang dengan Praktik Gizi Seimbang Mahasiswa Program Studi Pendidikan Dokter Angkatan 2013 Fakultas Kedokteran Universitas Sam Ratulangi. Jurnal e-Biomedik, 2(1).

Mariza, Y. Y., \& Kusumastuti, A. C. 2013. Hubungan antara kebiasaan sarapan dan kebiasaan jajan dengan status gizi anak sekolah dasar di Kecamatan Pedurungan Kota Semarang. Journal of Nutrition College, 2(1): 207-213.

Miko, A., \& Dina, P. B. 2016. Hubungan Pola Makan Pagi dengan Status Gizi pada Mahasiswi Poltekkes Kemenkes Aceh. AcTion: Aceh Nutrition Journal, 1(2): 83-87.

Muchtar, M., Julia, M., \& Gamayanti, I. L. 2011. Sarapan dan jajan berhubungan dengan kemampuan konsentrasi pada remaja. Jurnal Gizi Klinik Indonesia, 8(1): 28-35.

Niswah, I., Damanik, M. R. M., \& Ekawidyani, K. R. 2014. Kebiasaan Sarapan, Status Gizi, dan Kualitas Hidup Remaja SMP Bosowa Bina Insani Bogor. Jurnal Gizi dan Pangan, 9(2).

Noviani, K., Afifah, E., \& Astiti, D. 2016. Kebiasaan jajan dan pola makan serta hubungannya dengan status gizi anak usia sekolah di SD Sonosewu Bantul Yogyakarta. Jurnal Gizi dan Dietetik Indonesia (Indonesian Journal of Nutrition and Dietetics), 4(2): 97-104.

Nurwijayanti, N. 2018. Pola Makan, Kebiasaan Sarapan dan Status Gizi Berhubungan Dengan Prestasi Belajar Siswa SMK di Kota Kediri. Care: Jurnal Ilmiah Ilmu Kesehatan, 6(1): 54-63.

Perdana, F., \& Hardinsyah, H. 2013. Analisis Jenis, Jumlah, dan Mutu Gizi Konsumsi Sarapan Anak Indonesia. Jurnal Gizi dan Pangan, 8(1): 39-46.

Rosyidah, Z., \& Andrias, D. R. 2016. Jumlah Uang Saku dan Kebiasaan Melewatkan Sarapan Berhubungan dengan Status Gizi Lebih Anak Sekolah Dasar. Media Gizi Indonesia, 10(1): 16.

Sartika, R. A. D. 2012. Penerapan komunikasi, informasi, dan edukasi gizi terhadap perilaku sarapan siswa Sekolah Dasar. Kesmas: National Public Health Journal, 7(2):76-82.

Sasmito, P. D. 2015. Hubungan asupan zat gizi makro (karbohidrat, protein, lemak) dengan kejadian obesitas pada remaja umur 13-15 
tahun di propinsi DKI Jakarta (Analisis data sekunder Riskesdas 2010). Nutrire Diatita, 7(1): 16-23.

Soedibyo, S., \& Gunawan, H. 2016. Kebiasaan Sarapan di Kalangan Anak Usia Sekolah Dasar di Poliklinik Umum Departemen Ilmu Kesehatan Anak FKUI-RSCM. Sari Pediatri, 11(1): 66-70.
Saufika, A., Retnaningsih, A., \& Alfiasari, A. 2012 Gaya hidup dan kebiasaan makan mahasiswa. Jurnal Ilmu Keluarga dan Konsumen, 5(2): 157-165.

Wardoyo, H. A., \& Mahmudiono, T. 2013). Hubungan makan pagi dan tingkat konsumsi zat gizi dengan daya konsentrasi siswa sekolah dasar. Media Gizi Indonesia, 9(1), 4953. 